\title{
The Scottish ideal: \\ Lay education and training in the Church of Scotland
}

\author{
Liam Jerrold Fraser
}

Rev Dr Liam Jerrold Fraser is Minister of St Michael's, Linlithgow. He was formerly Church of Scotland Campus Minister at the University of Edinburgh, and was the first person in the Church of Scotland to be ordained into a Pioneer Ministry role. He is currently writing Mission in Contemporary Scotland, the first comprehensive introduction to mission in a Scottish context.

In recent years, there has been a growing consensus that lay leadership is vital for ministry and mission in a post-Christendom context. ${ }^{1}$ The continued decline of churchgoing means that fewer people will ever attend worship led by ordained clergy, raising the everyday witness and initiative of church members to new levels of importance. While the Church of Scotland has accepted the need for better education and training for church members, institutional reform in this direction has, however, been limited.

This article attempts to explain that lack of progress. We begin by examining how the theological and cultural heritage of the Kirk decisively shaped its attitude toward lay leadership in ministry and domestic mission, before examining a number of failed attempts to implement reform over the last two decades. We conclude with an overview of the Kirk's recent Radical Action Plan, and its proposals for the creation of a new education and training programme for all church members. This article argues that the Church of Scotland has not invested in lay education and training because, at least historically, it has not believed in lay leadership in worship, teaching, and domestic 
mission. This lack of investment means that the Kirk now lacks the infrastructure to adequately train its members and elders, leaving the future of lay education and training in doubt.

\section{The assumptions of history}

The Church of Scotland's attitude toward lay theological education and training has been decisively shaped by Reformed theology, and its historic opposition to two other branches of the Christian family: Roman Catholics and Anabaptists. Against the Roman Catholic church, Reformed theologians came to believe that ministry was evangelical rather than sacerdotal. It was by hearing and believing God's promises in the preached Word - and not by receiving communion, absolution, and other sacraments from a priest possessing the character indelebilis of episcopal ordination - that one was saved. ${ }^{2}$ Yet if salvation required the preaching of God's Word, it was essential that those preaching knew and understood that Word correctly. Protestant ministry therefore required a higher level of education than was commonly thought necessary for Roman Catholic priests. In opposition to certain strands of Anabaptist thought, however, the Reformed continued to believe that ordination was a normal prerequisite for teaching. Rather than baptised believers assuming the responsibility of preaching the Gospel as their talents and desires led them, Calvin believed that lay preaching led to disorder in the body of the Church, and the corruption of God's Word. Baptism alone was not enough. As Van der Borght puts it, 'In the Reformed theology of ministry, the priesthood of all believers hardly plays any part at all. ${ }^{3}$ By rejecting lay teaching and the continued existence of 'extraordinary ministries' such as evangelist and prophet, Calvin reduced the number of leadership positions open to church members, limiting these to the pastoral and disciplinarian office of the elder. ${ }^{4}$

When public feeling turned against the papacy in Scotland, John Knox and other Protestant churchmen were able to realise the vision of continental Reformed theologians in their homeland. As they possessed elite support, however, the Reformers were not only able to attempt the reform of the church but the whole of Scottish society. 
Central to these plans was education. As the First Book of Discipline explains, the reform of education was crucial for the advancement of the true Gospel and the ministry of the Kirk:

For as the youth must succeed to us so we ought to bee carefull that they have knowledge and erudition to profit and comfort that which ought to be most deare to us, to wit, the kirk and spouse of our Lord Jesus. ${ }^{5}$

While the First Book of Discipline was not fully enacted, much progress was made in the reform of universities, whose new schools of divinity were sometimes styled 'anti-seminaries' to emphasise their anti-sacerdotal ethos and integration with wider society. ${ }^{6}$

Positively, political support enabled the Church of Scotland to reform existing Scottish universities for the teaching of divinity rather than establishing its own seminaries. This saved the church resources, it directly and indirectly furthered the spread of Protestant ideas amongst the professions, and it allowed ministers to benefit from the rigour and prestige of a university education. Negatively, however, it left the Kirk highly dependent on the continuing Christian and Protestant complexion of Scottish higher education. The education of ministers at university also increased the possibility of the sacerdotal distinction between priests and laity being replaced by the educational distinction between ministers and everyone else.

Tendencies toward clericalism were moderated after the Reformation, however, through the presence of readers and exhorters. These non-ordained and somewhat provisional offices were a response to the shortage of educated ministers, yet also provided opportunities for church members. First, they allowed the non-ordained a role in the leading of pubic worship, acknowledging the giftings of those without university education and ordination. Second, and quite deliberately, the Scottish Reformers saw the offices of reader and exhorter as steps toward further education and eventual ordination. Along with ministers, readers and exhorters were expected to attend a weekly 'exercise' of bible study, commentary and preaching, an exercise that would eventually evolve into present-day Presbyteries. ${ }^{7}$ 
As more ministers were trained, however, the offices of reader and exhorter gradually grew redundant, and, an important source of lay theological education and training was lost. ${ }^{8}$ While the lay office of catechist took their place, this role did not come with any specific theological education or training over and above the catechesis and ministerial guidance that all Scots were subject to. While church members and elders could catechise, the Kirk - true to its Reformed heritage - continued to oppose lay worship leading and preaching. This was seen as late as 1799 in the infamous 'Pastoral Admonition' of the General Assembly, which decreed that no-one throughout the whole realm should listen to the lay Baptist 'Haldane preachers' or invite them to preach. ${ }^{9}$

More progress in lay theological training and education was made, however, with the office of lay missionary. This office had its origins in the proselytization of Roman Catholic areas of the highlands and islands through the Society in Scotland for the Promotion of Christian Knowledge (SSPCK) and the King's Bounty. ${ }^{10}$ It grew from this limited role, however, to encompass a variety of urban and rural leadership positions offered to church members, eventually becoming a distinct office in its own right.

While nineteenth-century churchmen such as Norman MacLeod were supportive of education and training for lay missionaries and other workers, this was a minority view. When proposals for the creation of a training institute for lay missionaries was raised in the later nineteenth century they were rejected, the Kirk preferring to use part-time divinity students than full-time lay missionaries. ${ }^{11}$ While Winter residential courses for lay missionaries were eventually established at the St Ninian's Mission in the Pleasance, Edinburgh, these were purposefully kept to a minimum. ${ }^{12}$ The reason for this intentional lack of investment in lay education and training was summed up in a General Assembly report of 1926:

They [lay missionaries] exercise a most worthy ministry. Yet, at the best, they are not a satisfactory substitute for the carefully trained ministry, which has always been our Scottish ideal. ${ }^{13}$ 
While impossible due to the personnel shortages occasioned by Presbyterian disunity, the Scottish ideal - that the majority of ministry and mission should be undertaken by the parish minister - finally came within reach through the reunification of the Church of Scotland in 1929. Reunification, accompanied by Parish readjustments and an aggressive re-assertion of the Kirk and its ministers as the protectors of Scottish nationhood, thereby reduced the number of roles open to lay leaders.

The post-war period, however, seemed to herald new opportunities for lay education and training. Seaside missions, area missions, industrial chaplaincies, and the Tell Scotland campaign all afforded ample opportunities for lay leadership, which were often supported with an element of education and training. ${ }^{14}$ There were also institutional legacies. The first legacy of the post-war 'turn to the laity' was the St Ninian's Centre in Crieff, led by Church of Scotland evangelist D. P. Thomson. StNinian's offered training to individuals and teams engaging in mission work, as well as being a place of respite. The second legacy of this post-war resurgence in lay ministry and leadership was Scottish Churches House. Founded and led by Robert Mackie and Ian Fraser, Scottish Churches House offered courses and workshops to enable church members to play a full part in church leadership, particularly in the developing area of ecumenism. ${ }^{15}$ These centres worked together with older institutions founded to serve mission abroad, such as $\mathrm{St}$ Colm's College. This flowering of lay education and training reached its apogee in the Scottish Churches Open College (SCOC). This ecumenical training initiative - validated through Napier University in Edinburgh - offered a range of theological and biblical courses to equip all the saints for the task of ministry.

This late flowering of lay education and training would soon wither and fade, however, due to the financial effects of numerical decline. After failing to become the Kirk's centre of training for lay missionaries, St Ninian's, Crieff closed in 2001. St Colm's followed in 2010, and Scottish Churches House in 2011. While in existence for less time than all of these, SCOC closed in 2003, amid a flurry of controversy. ${ }^{16}$ Since these closures, Scotland's national church has operated no independent training institution of any kind. 


\section{Semper reformanda, numquam reformata}

Around the time that SCOC was being wound-up, however, a new chapter in the Kirk's engagement with lay education and training was being written: Church Without Walls (CWW). Taking cognisance of numerical decline and the increasing marginalisation of the church in Scottish cultural life, CWW presented the General Assembly with a series of reforms to turn around the failing fortunes of the Kirk. Central to its proposals was the belief that the Kirk's traditional model of ministry was increasingly becoming irrelevant. This model was dependent, so the report argued, upon a Christendom context in which the laity were largely passive and uneducated, and is no longer suitable for a time when educational attainment is higher, and Christian concepts are not widely understood. ${ }^{17}$ Borrowing a familiar trope from charismatic church-planting movements such as that of Alan Hirsch, ${ }^{18}$ CWW argues that the gifts of the apostle, evangelist, and prophet are of equal importance to those of the teacher-pastor, and that the Church should identify and nurture these giftings amongst the non-ordained. As the report says:

Each person is a gift from God to the church, to be celebrated and nurtured. [...] Each congregation is to be a living college, where people learn to exercise their gifts in an environment of grace characterised by encouragement, humility, and cooperation. ${ }^{19}$

The report recognised that the development of these gifts would require support. Rather than looking to divinity schools, however, CWW suggests presbyteries should augment the education given through SCOC, and do more to support the development of leadership in worship, pastoral care and mission at parish level. ${ }^{20}$

In advancing these recommendations, however, CWW is curiously ambivalent about the ability of structural and financial reforms to effect the cultural change that is its primary focus. We thus find statements such as: 
[The] Church is not changed by recommendations or deliverances. $^{21}$

Change in the church will not be the result of people following through a long list of recommendations. ${ }^{22}$

The report, then, typically places structural reform in opposition to cultural reform, rather than seeing these forms of reform as interdependent. This assumption would have important consequences for the future of lay education and training.

In the years following CWW, there is a noteworthy absence of references to its proposals for the reform of lay training and education. Part of this lack of engagement arose from a focus upon the structural reform of central committees and presbyteries. Yet it also arose from the rejection of CWW's support of lay leadership by a considerable number of the Kirk's leaders.

The first sustained discussion of lay education came no less than four years after CWW was presented in the 2005 Board of National Mission Report. This is to be found not in the body of the report, however, but in Appendix 13. Appendix 13 repeats CWW's critique of the traditional pastor-teacher model, which it brands as a form of 'theological and structural heresy'. ${ }^{23}$ The Board argues for a dedicated pioneer training track for church members, with new financial and management structures similar to those outlined in the Church of England's Mission-shaped Church report. ${ }^{24}$ It also levels a blunt critique against the theological curriculum of Scottish divinity schools, which have "no appreciation of the missionary context in which we are working [...] The list was worthy of any genuine theological training, but it could have been produced in 1973 rather than $2003{ }^{\prime} .{ }^{25}$ As their placement in Appendix 13 may indicate, however, these views were offered only as 'starters', and the Board's report advanced no deliverances dealing with lay education and training.

We pick up the thread again in 2006 with the report of the Church Without Walls Planning Group. Following CWW's preference for cultural rather than institutional reform, the report outlines a series of events to inspire church members to undertake ground-level 
reform of the Kirk. These events culminated in a large conference at the Edinburgh International Conference Centre which, impressively, had representation from $44 \%$ of the congregations of the Church of Scotland. ${ }^{26}$

While the Planning Group was pursuing CWW's proposals for lay leadership through the cultural reform of the local church, the Kirk's other committees were slowly returning to the Scottish ideal. In the Mission and Discipleship Council report of 2007, for example, the Council discusses the development of a new missionary training programme for both lay and ordained called Invest, headed by Alan McWilliam and CWW leader Peter Neilson. The Council goes out of its way, however, to make it clear that Invest is 'NOT part of the Church of Scotland's selection and training processes' [original capitalisation]. ${ }^{27}$ The Ministries Council Report of 2008 furnishes more detail on the fortunes of new forms of ministry and mission, yet not in a positive way. The report begins by discussing new forms of ministry for the changed times, yet does not see these as requiring the empowerment of the laity. Instead, it describes the bringing together of elements of auxiliary ministry and the readership to create what is now Ordained Local Ministry. ${ }^{28}$

The final re-assertion of the Scottish ideal is found in the Ministries Council Reports of 2011 and 2012. The Council's 2011 report begins by stating its sincere belief that parish ministry is, and will always be, the bedrock ministry of the Church of Scotland, before going on to apologise to ministers if they have received the impression that parish ministry was not more important than other forms of ministry. ${ }^{29}$ The Ministries Council report of 2012 doubled down on this, repeating its previous apology and making it clear that when it sometimes spoke of 'the ministry of all God's people' this should be understood as something that is enabled through parish ministry. The Council neglects, however, to offer any new training mechanisms for ministers that might facilitate this enabling. ${ }^{30}$

Turning to analysis, a number of issues are evident to even the casual reader of General Assembly reports from this period. First, there are a range of competing voices within the Councils and Committees of the Kirk, and an absence of any long-term strategic thinking in relation to lay education and training. These power struggles relate not 
only to powerful personalities but to genuine disagreement over the theology and ecclesiology of ministry and mission. These conflicting views mean that, depending on who is in charge of from year to year, deliverances and instructions relating to new forms of training and education are either taken forward in the Kirk or - more commonly - not. This confirms the conclusion of John and Olive Drane that the Church of Scotland suffers from a 'muddled and fragmented' vision of ministry, a situation made worse by the constant turnover of personnel from Committees and central church staff posts. ${ }^{31}$

Second, this intra-ecclesial disagreement is compounded by genuine confusion as to how reform of lay leadership and training should come about. Is it through ground-level cultural change or institutional restructuring? Does it lie with central Councils and Committees, presbyteries, congregations, or individuals? Is it the responsibility of the Kirk at all, or does it lie with divinity schools? The reports give different - and conflicting answers - to these questions, something that increases a sense of inertia and incapacity, and reinforces the perception that the form of Presbyterianism that currently animates the Church of Scotland is not fit for purpose.

In this, the Church of Scotland compares unfavourably with the Church of England. Three years after CWW, the Church of England in 2004 not only argued for the importance of lay ministry and mission but did something better: it introduced educational, financial, and managerial changes to enable lay ministry and mission to grow and develop. ${ }^{32}$ While in a similar state of decline to the Kirk, through these reforms, the Church of England has managed to slow decline and in the case of London and some other areas - has even experienced growth.

\section{A radical future?}

The recent history of attempted reform of theological education in the Church of Scotland does not leave one with much confidence for the future. An institution that as recently as 2010 could produce a major report that claimed that Scotland was still a Christian country and had not undergone secularisation cannot be characterised as one with a charism for reading the signs of the times. ${ }^{33}$ Nevertheless, real 
change may now be underway. The General Assembly of 2019 passed a series of deliverances known as the 'Radical Action Plan'. Among the deliverances passed was one that addressed the need for:

a flexible education, training and support programme for every person in the Church including material on leadership ${ }^{34}$

This section of the Radical Action Plan argues that the Kirk should work with existing or new partners to produce a validated, accredited and accessible programme of education and training in which church members, elders, and candidates for ministry are trained together. ${ }^{35}$ While detailed plans for this new programme will be presented to the General Assembly of 2021, the Mission and Discipleship Council has already approved two pilot courses aimed at Church members in association with New College, University of Edinburgh. These courses - which explore Pioneer Ministry and the leading of public worship by the non-ordained - began in Autumn 2019, and will help to inform the final system of lay education and training approved by a future Assembly.

While these developments are to be welcomed, there are two unanswered questions that should lead us to be cautious regarding the future of lay education in the Kirk. The first concerns the institutional partners that will validate the modules and courses of study foreseen in the Radical Action Plan. According to the Plan, the topics to be included in any new programme of education should include 'discipleship, mission and pioneering, fresh expressions, children's and youth work, the role of eldership, and the identifying and nurturing of congregational gifts. ${ }^{36}$ These are a far cry from the current syllabi lamented by the Board of National Mission as being more worthy of ' 1973 rather than 2003', and contain a number of topics that are outwith the expertise of most Scottish divinity schools. This lack of expertise has arisen because - unlike other Christian churches - the Church of Scotland exercises almost no control over the divinity schools in which it trains its ministers. Even if the Kirk as has been recently proposed - reduces its academic partners to one or two, ${ }^{37}$ an education and training programme of the kind foreseen by the Radical Action Plan will require substantial investment. Given the 
unprofitability of theological education for universities, however, the Kirk will have to sweeten the deal with cash. ${ }^{38}$ If the Kirk is unwilling or unable to provide this level of investment then new academic partners will have to be found, or validation through institutions of higher education curtailed or abandoned.

The lack of profitability in theological education raises another, and more serious spectre: the simple disinterest of church members in new opportunities for education, training, and leadership. In the Church of England, the growth in educational opportunities for the laity was often driven by the laity themselves, who - in defiance of parish boundaries and clerical sensitivities - began to plant new churches and missional initiatives in significant numbers. ${ }^{39}$ Even accounting for differences of scale, little of this lay leadership and initiative has been seen north of the border. ${ }^{40}$ When the Panel on Review and Reform attempted to find vacant congregations who would be willing to forego a full-time minister of Word and Sacrament and receive training and support to lead their own church, they could not find a single volunteer. ${ }^{41}$ While the activities and initiatives of Church Without Walls captured the interest of a significant proportion of church members and elders, with the passing of time, and the secession of many of the Kirk's missionminded evangelicals into other denominations, reform may have come too late, with the historic potential of the laity having been largely lost.

\section{Conclusion}

While the Radical Action Plan offers a new direction for the Church of Scotland, as we have seen, its proposals for lay education and training represent a significant divergence from the traditions of the Kirk. The Church of Scotland has failed to make any substantial investment in lay theological education and training because, at least historically, it has not believed in lay leadership in worship and teaching. In this, it has stayed true to the Scottish ideal of ministry and mission being the primary preserve of ordained and educated ministers. In the face of unprecedented and possibly terminal decline, however, the question facing the Kirk is whether that ideal is still worth the cost. 


\section{Notes}

1 See, e.g., David J. Bosch, Transforming Mission: Paradigm Shifts in Theology of Mission (Maryknoll, NY: Orbis, 1991), 586-95; Church of England, Mission-shaped Church: Church Planting and Fresh Expressions of Church in a Changing Context (London: Church House Publishing, 2004), 135 and 147; Stuart Murray, Church After Christendom (Milton Keynes: Paternoster, 2004), 187-93; Mike Breen, Multiplying Missional Leaders: From Halfhearted Volunteers to a Mobilized Kingdom Force (Pawley's Island, SC: 3 Dimension Ministries, 2012); George Lings, The Day of Small Things: An Analysis of Fresh Expressions of Church in 21 Dioceses of the Church of England (Sheffield: Church Army, 2016), 181-88.

2 Eduardus Van der Borght, Theology of Ministry: A Reformed Contribution to an Ecumenical Dialogue (Leiden: Brill, 2007), 10, 100-02.

3 Ibid., 132.

4 John Calvin, Institutes of the Christian Religion (Peabody, Mass.: Hendrickson, 2009), IV.3.4 and IV.3.8.

5 James K. Cameron, ed., The First Book of Discipline (Edinburgh: Saint Andrew Press, 1972), 130.

6 James Kirk, Patterns of Reform (Edinburgh: T\&T Clark, 1989), 50.

7 Jack C. Whytock, “An Educated Clergy": Scottish Theological Education and Training in the Kirk and Secession, 1560-1850 (Milton Keynes: Paternoster, 2007), 29-32.

8 Ibid., 92f.

9 See D. W. Lovegrove, "Pastoral Admonition", in Dictionary of Scottish Church History and Theology, ed. Nigel M. de S. Cameron (Edinburgh: T\&T Clark, 1993), 647.

10 Andrew F. Walls, "Three Hundred Years of Scottish Missions", in Roots and Fruits: Retrieving Scotland's Missionary Story, ed. Kenneth R. Ross (Oxford: Regnum Books, 2014), $6 \mathrm{f}$.

11 Frank D. Bardgett, Devoted Service Rendered: The Lay Missionaries of the Church of Scotland (Edinburgh: Saint Andrew Press, 2002), 53-57. 
Ibid., 94-96, 273-78.

13 Quoted in ibid., 135.

14 For an overview of these initiatives, see John Highet, The Scottish Churches: A Review of their State 400 Years After the Reformation (London: Skeffington, 1960), 70-88.

15 See Alexander Forsyth, Mission by the People (Eugene, Or.: Pickwick, 2017), 193-99.

16 "Theologian Accuses Church of Betrayal", The Scotsman, 20 May 2003 https://www.scotsman.com/news-2-15012/theologianaccuses-church-of-betrayal-1-880115

17 Church of Scotland, Church Without Walls (Edinburgh: Parish Education Publications, 2001), 28.

18 See Alan Hirsch, The Forgotten Ways: Reactivating the Missional Church, 2nd ed. (Grand Rapids, Mich.: Brazos Press, 2016).

19 Church of Scotland, Church Without Walls, 26.

20 Ibid., 26-28.

21 Ibid., 9.

22 Ibid., 39.

23 Reports to the General Assembly of the Church of Scotland 2005, 20/77. (Reports to the General Assembly are hereafter cited as Reports, [year].)

24 Ibid.

25 Ibid., 20/77-8.

26 Reports, 2006 and 2007, 11/1-12 and 11/1-6.

27 Reports, 2007, 4/46.

28 Reports, 2008, $3 / 5$.

29 Reports, 2011, 4/44-45.

30 Reports, 2012, 4/11-4/22.

31 John Drane and Olive Fleming Drane, Reformed, Reforming, Emerging and Experimenting (Edinburgh: Church of Scotland, 2010), 38 .

32 Church of England, Mission-shaped Church, 125-49.

33 See Reports, 2010, 4/11-4/22.

34 Reports, 2019, Deliverance 2(g), 7/1.

35 Ibid., 7/14-7/16.

36 Ibid., 7/15.

37 Reports, 2010, 25/17-18. 
38 For an overview of the Kirk's relationship with Scottish divinity schools, see Doug Gay, Reforming the Kirk: The Future of the Church of Scotland (Edinburgh: Saint Andrew Press, 2018), 12027.

39 It was this reality that gave rise to Breaking New Ground in the early 1990s, and its successor Mission-shaped Church in the early 2000s.

40 Drane and Drane, Reformed, 39.

41 Reports, 2017, 11/5. 